\title{
Electrospinning of food-grade nanofibres from whey protein
}

Article

Accepted Version

Creative Commons: Attribution-Noncommercial-No Derivative Works 4.0

Zhong, J., Mohan, S. D., Bell, A., Terry, A., Mitchell, G. and Davis, F. J. (2018) Electrospinning of food-grade nanofibres from whey protein. International Journal of Biological Macromolecules, 113. pp. 764-773. ISSN 0141-8130 doi: https://doi.org/10.1016/j.ijbiomac.2018.02.113 Available at https://centaur.reading.ac.uk/76402/

It is advisable to refer to the publisher's version if you intend to cite from the work. See Guidance on citing.

Published version at: https://www.sciencedirect.com/science/article/pii/S0141813017345737

To link to this article DOI: http://dx.doi.org/10.1016/j.ijbiomac.2018.02.113

Publisher: Elsevier

All outputs in CentAUR are protected by Intellectual Property Rights law, including copyright law. Copyright and IPR is retained by the creators or other copyright holders. Terms and conditions for use of this material are defined in the End User Agreement.

\section{www.reading.ac.uk/centaur}

\section{CentAUR}

Central Archive at the University of Reading 
Reading's research outputs online 


\title{
Electrospinning of food-grade nanofibres from
}

\section{whey protein}

Jie Zhong ${ }^{1}$, Saeed D. Mohan, ${ }^{2, *}$, Alan Bell ${ }^{1}$, Ann Terry ${ }^{3}$, Geoffrey R. Mitchell ${ }^{4}$ and Fred J. Davis $^{2}$

1. Department of Food and Nutritional Science, University of Reading, Whiteknights, RG6 6AP, UK

2. Department of Chemistry, University of Reading, Whiteknights, RG6 6AD, UK

3. CoSAXS beamline, MAX IV Laboratory, Lund University, P.O. Box 118, SE-221 00 Lund, Sweden

4. Centre for Rapid and Sustainable Product Development, Rua de Portugal - Zona Industrial, 2430-028 Marinha Grande, Portugal

\begin{abstract}
In this study, electrospinning has been employed to produce micro to nano scale fibres of whey protein in order to investigate their potential for use in the food industry. Initially, spinning of pure whey protein proved challenging; so in order to facilitate the spinning of freshly prepared aqueous solutions, small amounts of polyethylene oxide (as low as $1 \% \mathrm{w} / \mathrm{w}$ in solution) were incorporated in the spinning solutions. The electrospun composite polyethylene-oxide/whey fibres exhibited diameters in the region of 100 to $400 \mathrm{~nm}$, showing the potential to build fibre bundles from this size up. Time-dependent examinations of pure whey protein aqueous solutions were conducted using rheometery and small angle neutron scattering techniques, with the results showing a substantial change in the solution properties with time and stirring; and allowing the production of fibres, albeit with large diameters, without the need for an additive. The spinability is related to the potential of the whey protein
\end{abstract}

\footnotetext{
*Email: s.d.mohan@ reading.ac.uk
} 
composites to form aggregate structures, either through hydration and interaction with neighbouring proteins, or through interaction with the polyethylene oxide.

Key words: whey protein, polyethylene oxide, electrospinning, dynamic viscosity, SANS

\section{Introduction}

Proteins found in food are an essential material required for the maintenance of human health. There are a variety of sources for food proteins, both from animal and plants. In this study we examine whey protein; a material comprised of a variety of globular proteins formed of the essential amino acids. Whey is derived from milk processing, produced as a by-product in the preparation of cheese and casein. Whey possesses both a nutritional benefit and functional properties along with a potentially high economic value, making it of particular use to the food industry. The functional properties of whey include features such as its solubility, absorption, water holding capacity, viscosity, emulsifying, foaming or gelation and these are beneficial aspects that can be utilised in food processing and consumption ${ }^{1,2}$. The modification of whey protein is of considerable interest if it is intended to improve its functional properties ${ }^{3}$ and novel applications for processed whey proteins are now growing. Amongst the more recent examples, whey has been recognized as a possible vehicle to deliver bioactive materials and pharmaceutical compounds ${ }^{4,5,6}$. The overall bulk properties of the whey protein will be dependent on the molecular interactions in the material with itself and its surroundings, which in turn can be influenced by how the material is processed1. The functional properties of the material will also impact on aspects relating to the sensory attributes of consumption in terms of texture and flavour ${ }^{7}$. In this study we investigate fibre production of globular whey protein on a micro and nano scale, which could be of potential 
use in the food industry as a form of textured food product, such as a synthetic meat. Meat from animal sources is made up cells containing proteins formed into fibrous bundles. As opposed to the synthetic meats made from tissue engineering practices ${ }^{8,9}$, the concept here investigates the use of electrospinning to produce fibre bundles of whey protein as a potential replacement for the fibre bundles that form the muscular tissue in meat. Thus typical diameters of the hierarchical structures of muscle fibres range from just below $10 \mathrm{~nm}$ through to $100 \mathrm{~nm}$ up to bundles of fibres of 100 micron or larger. ${ }^{10}$

Electrospinning is a simple method of producing continuous, long, ultra-fine fibres with diameters from a few micrometres down to a few nanometres with the aid of an electric field, ${ }^{11}$ thus electrospinning is ideal for forming larger bundles of fibres (up to a few 100 microns) made up from individual submicron diameters fibres, in line with the dimensions of the hierarchical structures described above. ${ }^{12}$ The technique relies on the response of polymer solutions to this electric field ${ }^{13}$ and compared with the limitations of conventional fibre forming technology ${ }^{14,15,16}$ the electrospinning technique produces "finer fibres" with greater surface areas per unit mass. This allows applications in several areas such as protective clothing, biomedical applications, pharmaceutical products and processes involving nanocatalysis ${ }^{17,18,19}$. In the case of whey protein solutions electrospinning with be dependent highly on the nature of the protein solution; for example, high concentrations of whey protein in solution can cause aggregation, which in turn will impact on the solutions properties such as its viscosity ${ }^{20}$. The protein native state can also be influenced by extreme $\mathrm{pH}$, cold temperature, high temperature, shear forces and chemical agents which again will greatly influence the solution states properties and the electrospinnability of the material ${ }^{21}$.

There have been previous studies examining the use of proteins in the electrospinning process; examples include collagen ${ }^{22}$, egg $\operatorname{protein}^{23}$ and wheat protein ${ }^{24}$. Unfortunately, whey protein in aqueous solvent has not yet been found to yield nanofibres successfully ${ }^{25}$, thus in 
order to successfully spin this material an electrospinnable carrier material must be used. Polyethylene oxide (PEO) is one kind of water-soluble polymer which had been utilized as a carrier polymer and has been shown to have a number of advantages for electrospinning, these include low toxicity allowing for its potential use as a food additive, and of course inherent electrospinning ability in its own right. PEO has been used as a carrier polymer in a biopolymer solution with silk ${ }^{26}$, soy protein ${ }^{27}$, eggshell protein ${ }^{28}$ and whey protein isolate ${ }^{29}$. The addition of PEO improves the ability of electrospinning by modifying the physical properties of the blended solution, especially the degree of the chain entanglements/associations ${ }^{30}$. The reduction of electrical conductivity of the biopolymer solution with the addition of PEO has also been attributed to be the cause of the improvement in the materials electrospinning characteristics ${ }^{31,32,33}$.

The objective of this study was to find the optimal routes to forming submicron fibres of whey protein both with and without the presence of PEO, and relating the resultant fibre morphology to solution properties. Understanding of the morphologies formed and its relation to the solution properties are a step forward in producing fibre bundles that have a potential use in textured food products.

\section{Experimental section}

\subsection{Purification and freeze drying}

Whey Protein Concentrate (WPC) powder was purchased from Volactive Functional Food Product Company (Royston, UK). The defatted WPC powder was found to contain in excess of $80 \%$ whey protein, the remainder mainly consisting of lactose and minerals, and trace 
amounts of fat (Molecular weights $\left(\mathrm{M}_{\mathrm{w}}\right), 342$ to 20,000 Daltons). The concentration and molecular weights of the protein fractions that make up the WPC powder are given in Table 1:

Table 1: Concentration of Protein fractions in the WPC powder.

\begin{tabular}{|c|c|c|}
\hline Protein & Percentage of Protein & Molecular weight (kDa) \\
\hline$\beta$-lactoglobulin & $43-48$ & 18.5 \\
\hline$\alpha$ - lactalbumin & $14-18$ & 14.178 \\
\hline Bovine serum albumin & $1-2$ & 66.5 \\
\hline Immunoglobulin G & $1-3$ & 150 \\
\hline Lactoferrin & $<1$ & $76-80$ \\
\hline Glycomacropeptide & $24-28$ & 8 \\
\hline
\end{tabular}

The rehydrated WPC powder was subsequently dialyzed (cut off $\mathrm{M}_{\mathrm{W}} 12,000-14,000$ Daltons) against several changes of distilled water (over 24 hours at $18^{\circ} \mathrm{C}$ ) to remove all of the lower molecular weight components (Lactose, minerals, and fat). Following dialysis, samples of the whey protein were freeze dried in order to facilitate storage for longer periods of time.

The viscosity of the test solutions were measured using a Bohlin Rheometer (Gemini 200 Rotonetic drive 2) (Malvern Instrument Ltd, Worcestershire, UK). Scanning electron microscope was performed using SEM 360 (Cambridge Instrument). Samples of foil coated with fibres were mounted on small SEM brass stubs and prepared by coating with a thin layer of gold. Image-analytical software (Scandium analytical software) was used to visualise the fibres and determine the diameters of the various fibrous product. Statistical analysis of solution viscosity with different amount of PEO and different amount of WPC were performed using two way ANOVA, the changes of solution viscosity and fibre diameter with time were carried out using one way ANOVA $(\mathrm{p}<0.05)$, using SPSS 17 statistical software. 


\subsection{Electrospinning}

Electrospinning was performed using a Glassman's high voltage power supply capable of delivering $0-30 \mathrm{kV}$ with respect to ground. Solutions were loaded into a $5 \mathrm{~mL}$ glass syringe fitted with a 22 gauge Luer lock metal needle $(0.413 \mathrm{~mm}$ internal diameter) of length $50 \mathrm{~mm}$ to which the high voltage supply was attached. The solution flow rate was controlled by a Razel scientific syringe pump with flow rates varying from $1-3 \mathrm{~mL} / \mathrm{hr}$. The distance between the flat aluminium collection plate and needle tip was $10 \mathrm{~cm}$ and the applied voltage for each polymer solution was varied between $7.5 \mathrm{kV}-25 \mathrm{kV}$ dependant on the sample properties observed during electrospinning.

\subsection{Small angle neutron scattering experiment}

Small angle neutron scattering experiment were carried out at the ISIS (STFC facility Rutherford Appleton Laboratory, Didcot, UK) on the LOQ small angle diffractometer ${ }^{34}$. An incident beam diameter of $12 \mathrm{~mm}$ was employed. A wavelength range of $2.2 \AA$ to $10 \AA$ providing a scattering vector, Q range $0.006 \AA^{-1}-0.25 \AA^{-1}$ (Where $|\mathrm{Q}|=4 \pi \sin \theta \lambda$, where $2 \theta$ is the scattering angle). Deuterated solutions were loaded into a quartz cuvette 'tank' cell with $2 \mathrm{~mm}$ path length, which were then loaded onto the LOQ sample changer for the neutron scattering measurements. In order to obtain a good signal-to-noise ratio on the scattering data, each sample was run for 30 - 90 min to accumulate sufficient signal (the low concentration polymer solutions needed a long collection time). Data was placed on an absolute scale in accordance with standard procedure by measurement of a standard solid hydrogenous/perdeuterated blend of polystyrene ${ }^{35}$. Scattering data was obtained on the 2dimensional ORDELA area detector and using instrument specific software, was radially 
averaged and corrected for sample transmission and background to provide a 1-dimensional plot of the differential scattering cross section as a function of the scattering vector.

\section{Results and Discussion}

Aqueous solutions of the dialysed WPC material was found to be almost impossible to electrospin into fibres under any of the possible electrospinning conditions, with attempts carried out under various solution concentrations, applied voltages and needle tip to collector distances. Observations of the results using SEM and in-situ high speed camera analysis showed that the material deposited as deformed droplets. Images obtained with a high speed camera (See supplementary data) showed the droplet at the needle tip deforms and is pulled towards the grounded target electrode (right hand side of images, not visible). The jet was found to break up on transit to form droplets that were deposited onto the foil. Due to the globular nature of the protein we attribute this behaviour to the lack of potential for chain entanglements, which are required for the electrospinning process to successfully prepare fibrous material. On the basis of these initial findings, a polymer (PEO) was added in order to facilitate the spinning.

\subsection{WPC-PEO}

As discussed previously, PEO has been reported to interact with a number of polymeric protein materials in order to produce electrospinnable "blends" 36 . It has been included in polymer blends for its ability to "carry" small quantities of essentially insoluble material, and incorporate it into any subsequent fibres produced ${ }^{37}$. This made it a suitable 
"carrier" system for the WPC material in this study. Several examples of spun material are shown below in Figure 1 and a summary of the results of electrospinning and viscosity data for various solutions are shown in Table 2 . 


\begin{tabular}{|c|c|c|c|c|c|c|c|c|c|c|}
\hline & & $\begin{array}{l}0 \% \mathrm{w} / \mathrm{w} \\
\mathrm{PEO}\end{array}$ & $\begin{array}{l}1 \% \mathrm{w} / \mathrm{w} \\
\mathrm{PEO}\end{array}$ & $\begin{array}{l}2 \% \mathrm{w} / \mathrm{w} \\
\mathrm{PEO}\end{array}$ & $\begin{array}{l}3 \% \mathrm{w} / \mathrm{w} \\
\mathrm{PEO}\end{array}$ & $\begin{array}{l}5 \% \mathrm{w} / \mathrm{w} \\
\mathrm{PEO}\end{array}$ & $\begin{array}{l}10 \% \\
w / w \\
\text { PEO }\end{array}$ & $\begin{array}{l}15 \% \mathrm{w} / \mathrm{w} \\
\mathrm{PEO}\end{array}$ & $\begin{array}{l}20 \% \\
w / w \\
\text { PEO }\end{array}$ & $\begin{array}{l}25 \% \\
w / w \\
\text { PEO }\end{array}$ \\
\hline \multirow{3}{*}{$\begin{array}{l}0 \% \\
\text { WPC }\end{array}$} & A & - & Beads & Beads & Beads & Beads & Beads & Beads & Beads & Fibres \\
\hline & B & - & $\begin{array}{l}0.035 \\
\pm 0.02\end{array}$ & $\begin{array}{c}0.093 \\
\pm 0.041\end{array}$ & $\begin{array}{c}0.219 \\
\pm 0.084\end{array}$ & $\begin{array}{c}1.131 \\
\pm 0.143\end{array}$ & $\begin{array}{c}2.316 \\
\pm 0.219\end{array}$ & $\begin{array}{c}4.374 \\
\pm 0.304\end{array}$ & $\begin{array}{c}9.257 \\
\pm 0.379\end{array}$ & $\begin{array}{c}15.3 \\
\pm 0.673\end{array}$ \\
\hline & $\mathrm{C}$ & - & - & - & - & - & - & - & - & \\
\hline \multirow{3}{*}{$\begin{array}{l}5 \% \\
\text { w/w } \\
\text { WPC }\end{array}$} & A & Beads & Beads & Beads & Beads & Beads & Beads & $\begin{array}{l}\text { Beads, } \\
\text { Fibres }\end{array}$ & $\begin{array}{l}\text { Beads, } \\
\text { Fibres }\end{array}$ & Fibres \\
\hline & B & $\begin{array}{l}0.062 \\
\pm 0.039\end{array}$ & - & - & - & - & - & $\begin{array}{c}6.194 \\
\pm 1.438 \\
\end{array}$ & $\begin{array}{r}13.810 \\
\pm 1.579 \\
\end{array}$ & $\begin{array}{r}58.498 \\
\pm 2.422 \\
\end{array}$ \\
\hline & C & - & - & - & - & - & - & $\begin{array}{l}0.19 \pm \\
0.071\end{array}$ & $\begin{array}{l}0.22 \pm \\
0.165\end{array}$ & $\begin{array}{l}0.29 \pm \\
0.220\end{array}$ \\
\hline \multirow{3}{*}{$\begin{array}{l}10 \% \\
\text { w/w } \\
\text { WPC }\end{array}$} & A & Beads & Beads & Beads & Beads & Beads & Fibres & Fibres & Fibres & Fibres \\
\hline & B & $\begin{array}{c}0.184 \\
\pm 0.092\end{array}$ & - & - & - & - & $\begin{array}{c}4.582 \\
\pm 0.674\end{array}$ & $\begin{array}{l}16.667 \\
\pm 1.987\end{array}$ & $\begin{array}{l}65.022 \\
\pm 1.525\end{array}$ & $\begin{array}{c}89.732 \\
\pm 2.77\end{array}$ \\
\hline & $\mathrm{C}$ & - & - & - & - & - & $\begin{array}{l}0.12 \pm \\
0.060\end{array}$ & $\begin{array}{l}0.21 \pm \\
0.134\end{array}$ & $\begin{array}{l}0.29 \pm \\
0.208\end{array}$ & $\begin{array}{l}0.27 \pm \\
0.164\end{array}$ \\
\hline \multirow{3}{*}{$\begin{array}{l}15 \% \\
\text { w/w } \\
\text { WPC }\end{array}$} & A & Beads & Beads & Beads & Beads & Fibres & Fibres & Fibres & Fibres & Fibres \\
\hline & B & $\begin{array}{c}0.358 \\
\pm 0.095\end{array}$ & - & - & - & $\begin{array}{c}0.911 \\
\pm 0.211\end{array}$ & $\begin{array}{l}8.544 \\
\pm 0.674\end{array}$ & $\begin{array}{l}59.902 \\
\pm 2.553\end{array}$ & $\begin{array}{r}74.48 \\
\pm 2.248\end{array}$ & $\begin{array}{r}95.089 \\
\pm 3.012\end{array}$ \\
\hline & $\mathrm{C}$ & - & - & - & - & $\begin{array}{l}0.13 \pm \\
0.075\end{array}$ & $\begin{array}{l}0.21 \pm \\
0.092\end{array}$ & $\begin{array}{l}0.29 \pm \\
0.180\end{array}$ & $\begin{array}{l}0.24 \pm \\
0.177\end{array}$ & $\begin{array}{l}0.22 \pm \\
0.102\end{array}$ \\
\hline \multirow{3}{*}{$\begin{array}{l}20 \% \\
\text { w/w } \\
\text { WPC }\end{array}$} & A & Beads & Beads & Beads & $\begin{array}{l}\text { Beads, } \\
\text { Fibres }\end{array}$ & $\begin{array}{l}\text { Beads, } \\
\text { Fibres }\end{array}$ & Fibres & Fibres & Fibres & - \\
\hline & B & $\begin{array}{c}0.729 \\
\pm 0.114 \\
\end{array}$ & - & - & $\begin{array}{r}1.635 \\
\pm 0.298 \\
\end{array}$ & $\begin{array}{l}2.734 \\
\pm 0.474 \\
\end{array}$ & $\begin{array}{l}9.226 \\
\pm 1.17 \\
\end{array}$ & $\begin{array}{r}77.283 \\
\pm 1.349 \\
\end{array}$ & $\begin{array}{r}98.773 \\
\pm 1.995 \\
\end{array}$ & - \\
\hline & C & - & - & - & $\begin{array}{l}0.12 \pm \\
0.105\end{array}$ & $\begin{array}{l}0.14 \pm \\
0.050\end{array}$ & $\begin{array}{l}0.31 \pm \\
0.201\end{array}$ & $\begin{array}{l}0.34 \pm \\
0.323\end{array}$ & $\begin{array}{l}0.2 \pm \\
0.10\end{array}$ & - \\
\hline \multirow{3}{*}{$\begin{array}{l}25 \% \\
\text { w/w } \\
\text { WPC }\end{array}$} & A & Beads & Beads & Beads & $\begin{array}{l}\text { Beads, } \\
\text { Fibres } \\
\end{array}$ & Fibres & Fibres & Fibres & - & - \\
\hline & B & $\begin{array}{l}1.236 \\
\pm 0.21 \\
\end{array}$ & - & - & $\begin{array}{c}3.062 \\
\pm 0.501 \\
\end{array}$ & $\begin{array}{c}5.015 \\
\pm 0.945 \\
\end{array}$ & $\begin{array}{r}23.236 \\
\pm 1.303 \\
\end{array}$ & $\begin{array}{c}159.715 \\
\pm 5.839 \\
\end{array}$ & - & - \\
\hline & C & - & - & - & $\begin{array}{l}0.17 \pm \\
0.044\end{array}$ & $\begin{array}{l}0.19 \pm \\
0.099\end{array}$ & $\begin{array}{l}0.32 \pm \\
0.181\end{array}$ & $\begin{array}{l}0.25 \pm \\
0.151\end{array}$ & - & - \\
\hline \multirow{3}{*}{$\begin{array}{l}30 \% \\
\text { w/w } \\
\text { WPC }\end{array}$} & A & Beads & $\begin{array}{l}\text { Beads, } \\
\text { Fibres } \\
\end{array}$ & $\begin{array}{l}\text { Beads, } \\
\text { Fibres } \\
\end{array}$ & Fibres & Fibres & Fibres & - & - & - \\
\hline & B & $\begin{array}{c}1.876 \\
\pm 0.332 \\
\end{array}$ & $\begin{array}{c}7.731 \\
\pm 0.651 \\
\end{array}$ & $\begin{array}{r}8.476 \\
\pm 0.512 \\
\end{array}$ & $\begin{array}{r}15.073 \\
\pm 1.232 \\
\end{array}$ & $\begin{array}{l}30.661 \\
\pm 1.692 \\
\end{array}$ & $\begin{array}{r}76.971 \\
\pm 2.881 \\
\end{array}$ & - & - & - \\
\hline & $\mathrm{C}$ & - & $\begin{array}{c}0.1 \pm \\
0.072\end{array}$ & $\begin{array}{l}0.14 \pm \\
0.058\end{array}$ & $\begin{array}{l}0.28 \pm \\
0.150\end{array}$ & $\begin{array}{l}0.29 \pm \\
0.112\end{array}$ & $\begin{array}{l}0.27 \pm \\
0.256\end{array}$ & - & - & - \\
\hline \multirow{3}{*}{$\begin{array}{l}35 \% \\
\text { w/w } \\
\text { WPC }\end{array}$} & A & Beads & Fibres & Fibres & Fibres & Fibres & - & - & - & - \\
\hline & B & $\begin{array}{r}2.791 \\
\pm 0.351 \\
\end{array}$ & $\begin{array}{r}14.279 \\
\pm 1.155 \\
\end{array}$ & $\begin{array}{r}19.429 \\
\pm 2.158 \\
\end{array}$ & $\begin{array}{l}25.125 \\
\pm 2.124 \\
\end{array}$ & $\begin{array}{r}75.69 \\
\pm 2.665 \\
\end{array}$ & - & - & - & - \\
\hline & C & - & $\begin{array}{c}0.2 \pm \\
0.113\end{array}$ & $\begin{array}{l}0.31 \pm \\
0.180\end{array}$ & $\begin{array}{c}0.3 \pm \\
0.201\end{array}$ & $\begin{array}{l}0.37 \pm \\
0.211\end{array}$ & - & - & - & - \\
\hline
\end{tabular}

Table 2. Results of electrospinning ability and viscosity measurements of fresh prepared WPC/PEO blend solutions. A :the state of electrospun materials; B: the dynamic viscosity (Pa.s) of WPC/PEO complex polymer solution $(n=9 \pm s d) ; \mathbf{C}$ : the diameter of electrospun fibre $(\mu \mathrm{m} ; \mathrm{n}=90 \pm \mathrm{sd})$; the shaded area represents the range of fibre forming solutions 
It was not possible to produce electrospun material from concentrations of the blended material over a certain concentration (Table 2) due to the resulting high solution viscosities.
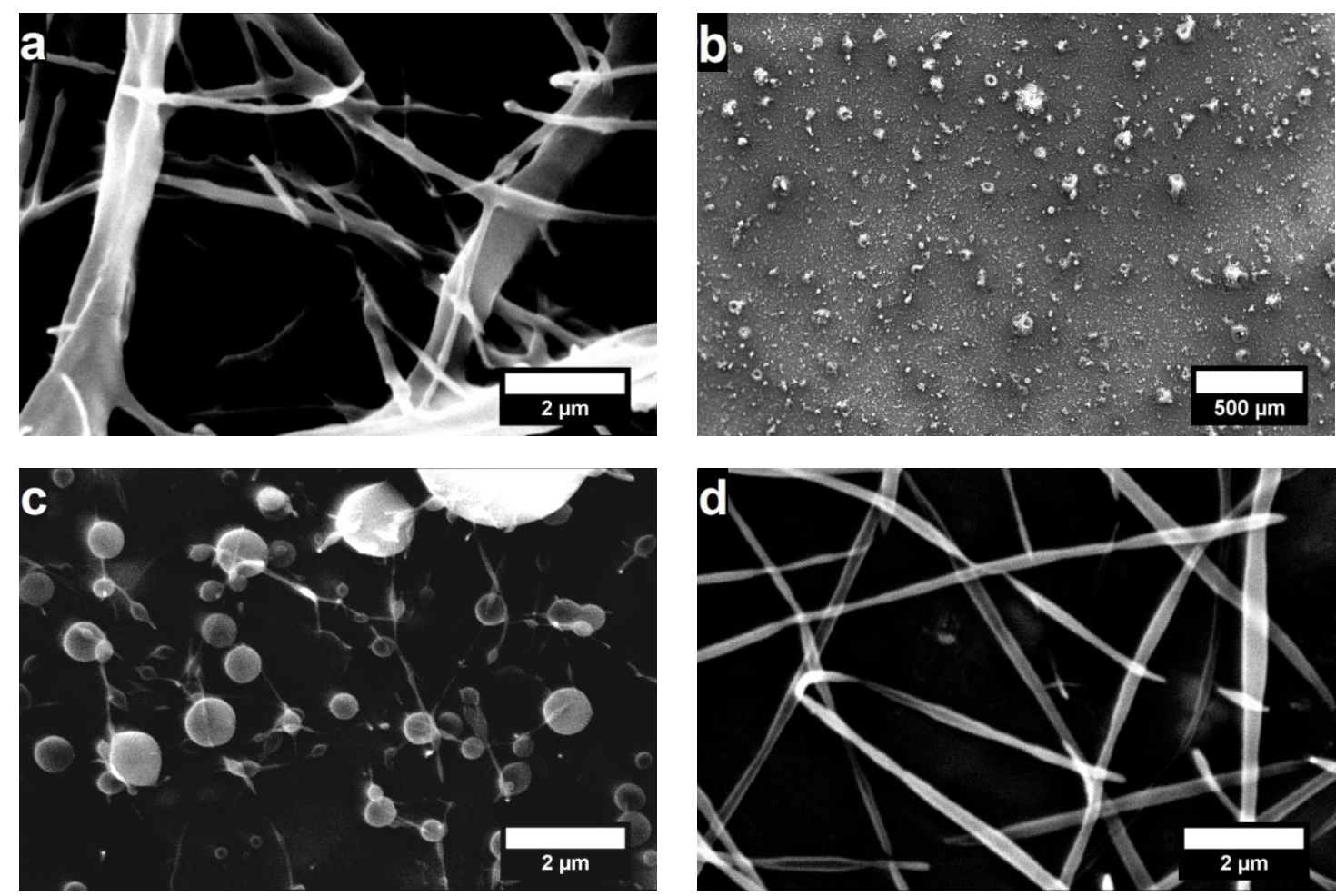

Figure 1. Typical SEM micrographs of electrospun material produced from a) $25 \% \mathrm{w} / \mathrm{w}$ PEO b) $35 \% \mathrm{w} / \mathrm{w}$ $\mathrm{WPC}$ c) $30 \% \mathrm{w} / \mathrm{w} \mathrm{WPC}+1 \% \mathrm{w} / \mathrm{w}$ PEO and d) $35 \% \mathrm{w} / \mathrm{w} \mathrm{WPC}+1 \% \mathrm{w} / \mathrm{w}$ PEO

In many previous studies, (e.g. electrospinning of fibres of poly $\varepsilon$ - caprolactone), the viscosity has been shown to play an important role in the process and the formation of electrospun fibres ${ }^{38,39}$. In view of this, control of the overall viscosity of the test solutions was likely to be a key factor in the process. Mixtures of PEO and WP varying in ratio and concentration in aqueous solution provided a wide range of viscosities varying between (1 160) Pa.s. The viscosity of the PEO/WP solution blends were significantly influenced by both the presence of either constituent $(\mathrm{p}<0.05)$. The addition of low concentrations of PEO $(1 \%$ $\mathrm{w} / \mathrm{w})$ to the WP solutions significantly increased the overall viscosity, for example, at $35 \%$ w/w WP the solution had a viscosity of $\sim 2.8$ Pa.s which increased to $\sim 14.3$ Pa.s when $1 \%$ of PEO was added. This implies a level of synergism as the $1 \% \mathrm{w} / \mathrm{w}$ PEO has a viscosity of 0.03 Pa.s, i.e. a considerable degree of interaction is present between the WP and the PEO 
molecules.

For cases in which there was a low polymer solution concentration and therefore a lower viscosity, the electrospun material tended to be in the form of beaded fibres ${ }^{39}$ (Figure 1c). Such beads have generally been considered to be undesirable 'by-products' or "defects" in the fibres ${ }^{40}$. The morphology of the electrospun product changed with increasing polymer solution concentration, from droplets, to beaded fibres, to spindle-like rod and then to uniform fibres (Figure $1 \mathrm{~b}-1 \mathrm{~d}$ ). At the correct fraction of PEO/WP and when the total solid mass dissolved in the polymer solution exceeds a critical value, the fibres produced by the PEO/WP blends were essentially uniform and on a nanoscale with diameters between $~ 100$ $400 \mathrm{~nm}$ (Figure 1d, Table 2). These fibres could be produced in high yields and were continuous, i.e. unbroken and uniform along their length with no signs of beading. The fibres did exhibit some degree of asymmetry, often being observed to have a "flattened" or "ribbon like" structure; this flattening process has been described by Koombhongse, Liu, and Reneker ${ }^{41}$ who attribute the ribbon formation to the initial development of a skin which collapses when the solvent evaporates. The formation of these ribbons (as distinct from cylindrical fibres) allows the ready observation of a pronounced overall "twist". Twisted fibres have often been associated with the presence of chirality in the polymeric material, ${ }^{42}$ although chirality is not a prerequisite for twisting, and helices of opposite chirality may be produced from the same material. ${ }^{43}$ There may be other mechanism for the formation of helices such as buckling at the collector; in the case of cellulose the behaviour has been attributed to the nonuniform deformation of filaments in the presence of a liquid crystalline phase. ${ }^{44}$

We attribute the observed behaviour to PEO carrying the whey protein by acting as a scaffold, forming non-covalent bonds with the WPC material, binding it together. This is partially substantiated from reports in the literature of weak hydrophobic interactions between PEO and proteins, as well as reports of a combination of electrostatic and 
hydrophobic interactions. ${ }^{45,4647,48}$ Therefore, it can be speculated that the non-covalent interaction played a vital role on the complex polymer system and the electrospinning process. In addition to the PEO acting as a carrier, its inclusion to the solutions resulted in an optimal solution viscosity, a key factor for continuous fibre generation. It was observed that if the preparation was not standardized (2 hours with gentle stirring for the "fresh" solutions), then the resulting viscosities varied considerably. This suggested a "dynamic" process which could be affected by time. The viscosity of whey protein solution has been previously reported to be related to their level of hydration in the solution state ${ }^{49}$.

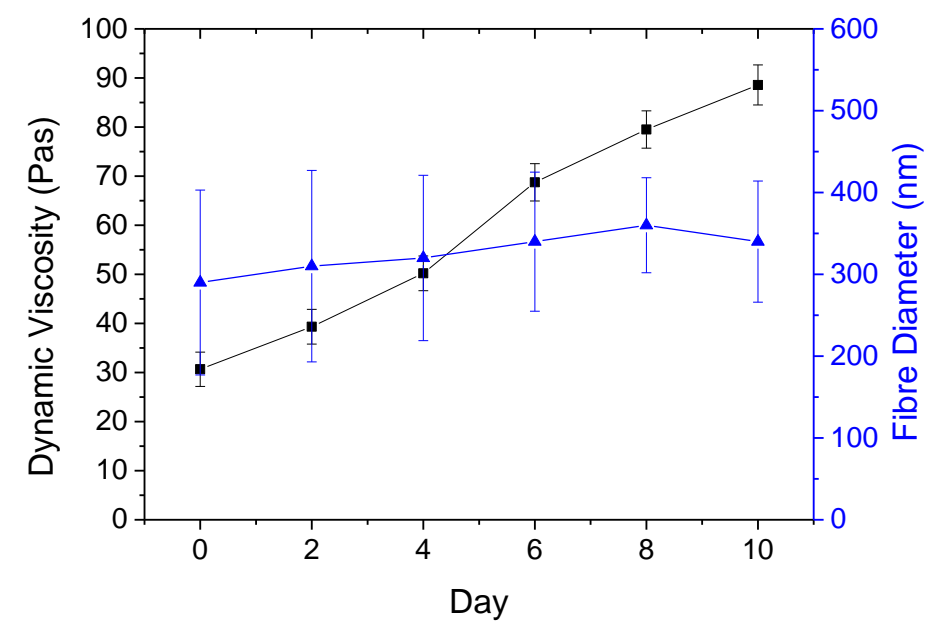

Figure 2: Data on dynamic viscosity ( $\mathbf{\square})$ and the fibre diameters $(\boldsymbol{\Delta})$ changes observed for a solution of $30 \%$ w/w WPC $+5 \%$ w/w PEO over a 10 day period.;(Sample sizes Dynamic viscosity, $\mathrm{n}=9 \pm$ sd; fibre size, $\mathrm{n}=90 \pm \mathrm{sd})$

Figure 2 summarizes the change of viscosity for the blended solution as a function of time over a 10 day period. A significant change to the viscosity was observed over this time period, increasing from 30.7 Pa.s on the initial day of the solution preparation to 88.5 Pa.s by day 10. It was believed that the increasing viscosity could be due to the aggregation of whey protein molecules. Viscosity measurements of PEO solutions over the same 10 day period showed no variation, further supporting the hypothesis that the Whey protein interactions are responsible for the impact on the observed results for the blended solutions. The changes in 
the solution viscosity over this time period promoted the formation of more uniform fibres when electrospun as viewable in Figure 3 for a $30 \% \mathrm{WPC}+5 \%$ PEO w/w material over a 10 day period.
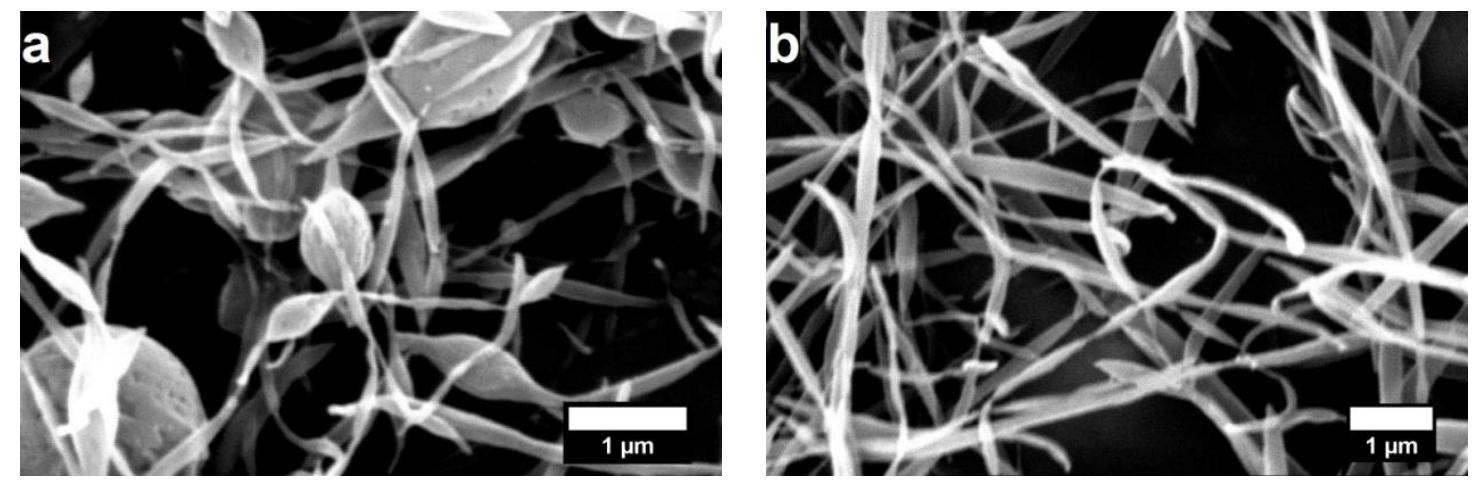

Figure 3: SEM micrographs of electrospun materials produced from $30 \% \mathrm{w} / \mathrm{w} \mathrm{WPC}+5 \% \mathrm{w} / \mathrm{w}$ PEO blended polymer solution a) 0 days and b) 10 days after solution preparation.

The average fibre size of the WP-PEO fibres increased from a mean diameter of $290 \mathrm{~nm}$ at day 0 to $360 \mathrm{~nm}$ by the $8^{\text {th }}$ day after preparation. Along with the change in fibre dimensions it was also observed that the electrospun fibre morphology changed from bead linked fused fibres (Figure 3a) to bead free short fibres (Figure 3b). Bead-free fibres were observed from Day 6 when the viscosity had reached approximately 68.7 Pas along with a narrowing of the fibre diameter distribution (Figure 2).

\subsection{WPC}

Based on above findings, whey protein aggregation may vary with time, leading to increases in viscosity. Examination of the viscosity was conducted for both stirred and nonstirred WPC solutions at various concentrations over a period of several days (Figure 4), with attempts to electrospin the pure material being conducted as time passed. 


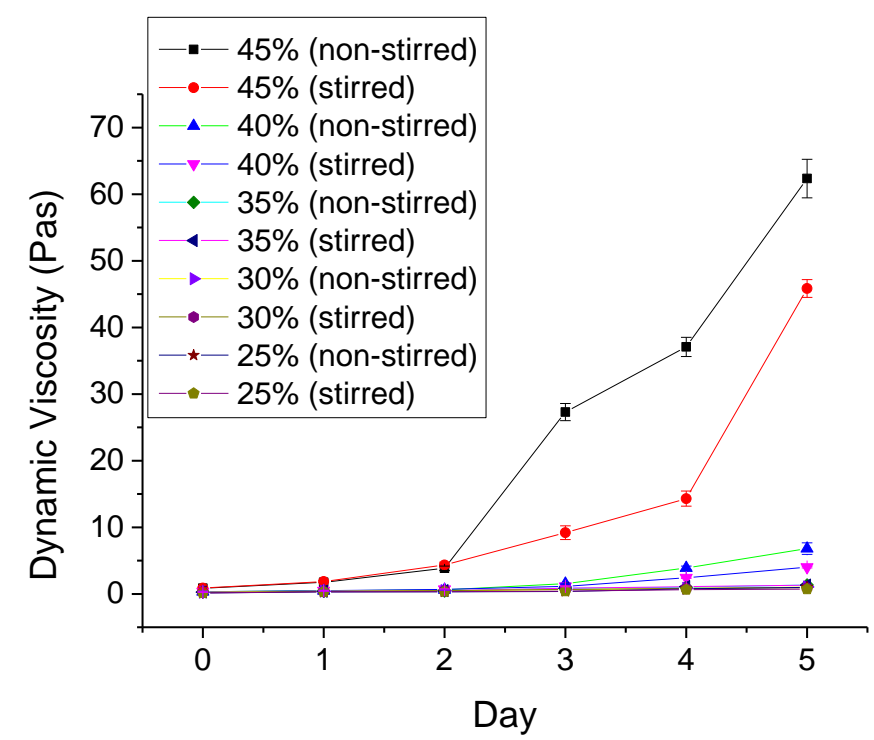

Figure 4: The dynamic viscosity of both stirred and non-stirred WPC polymer solution with varying concentration at $1 \mathrm{~Hz}$ over time from Day 0 to Day5. (Sample size $n=9 \pm s d$ )

Figure 4 shows that the dynamic viscosity increased with time and concentration, in line with the results of Hermansson, $1975 .{ }^{50}$ At concentrations of whey protein solution lower than $40 \%$, the dynamic viscosity of all samples was not obviously influenced by time or stirring during the first two days. During the time period the most notable variation in viscosity is associated with the difference in whey protein concentration amongst the samples. Between days 2 - 5 the dynamic viscosity of the samples was observed to increase more notably from its initial value. When the concentration of whey protein solutions was greater than or equal to $40 \% \mathrm{w} / \mathrm{w}$, the dynamic viscosity of both the stirred and non-stirred samples was minimally affected by time over the first two days, however it was observed to increase very rapidly after this period, similar to the observations made with the lower concentrations. The dynamic viscosity of the non-stirred sample was nearly twice as high as the stirred sample at $40 \%$ and $45 \% \mathrm{w} / \mathrm{w}$ solution from day 2 to day 3 . This may be because the non-stirred whey solution at high concentration (> 35\%) more readily formed larger aggregated structures or gel like structures. ${ }^{51}$ 
Small Angle Neutron Scattering (SANS) was used to probe the WPC solutions (in deuterium oxide), examining the impact of concentration and time on the solution properties. SANS offers the ability to measure the average size and shape of particles in a solution as well as the structural development in solutions at high concentration (See supplementary). Figure 5 shows SANS data from the whey protein solutions at different concentrations varying from dilute solutions, where the proteins are isolated from one another, to a more concentrated regime where the proteins interact with one another. What is immediately obvious is the development of structure at high concentration $\sim 35 \% \mathrm{w} / \mathrm{w}$ where a peak at $\mathrm{Q} \sim 0.03$ starts to develop (Figure 5 - indicated by a solid arrow). We attribute this peak development to the presence of aggregated material. Data for the peak analysis is given in Table 3, which shows the peak value of $\mathrm{Q}$ increases as the concentration increases. At $50 \% \mathrm{w} / \mathrm{w}$ the whey protein appeared to start to precipitate out of the solution.

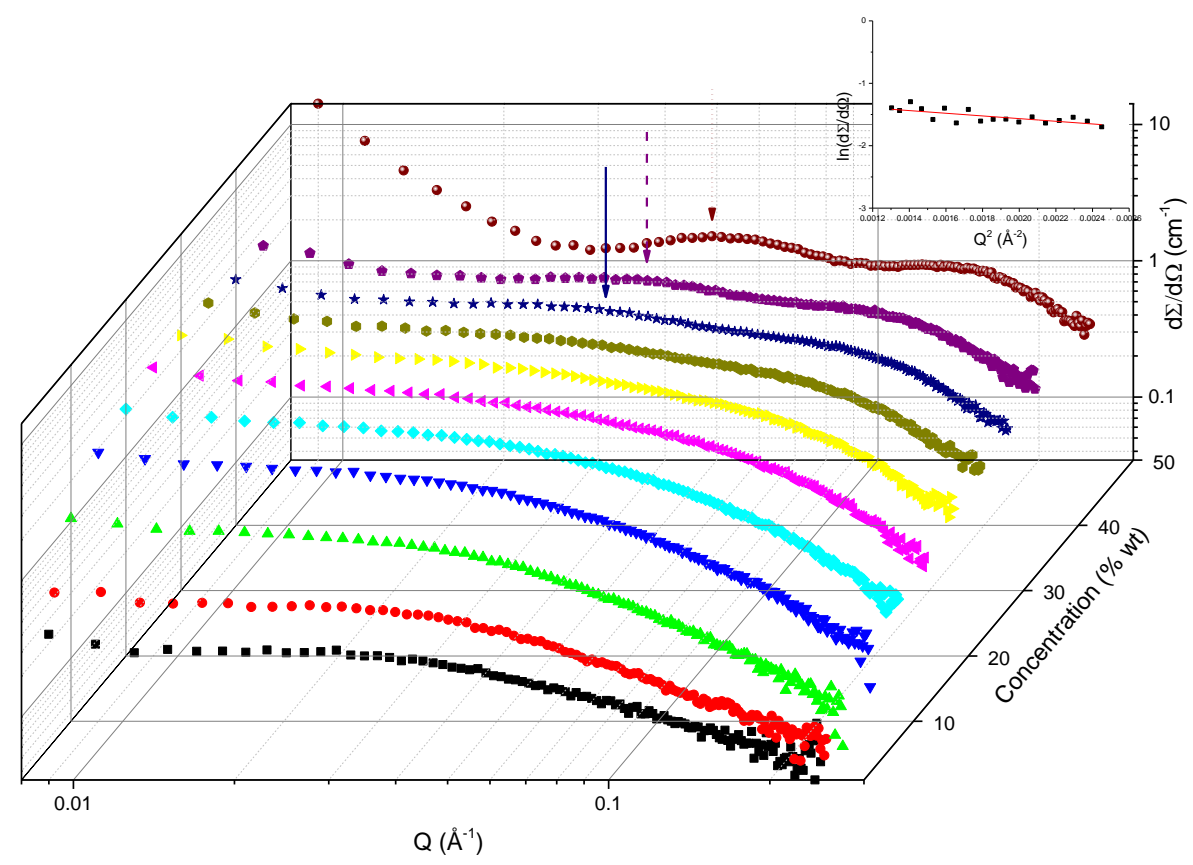

Figure 5: SANS data of whey in $\mathrm{D}_{2} \mathrm{O}$ with concentrations varying from $1 \%$ wt to $50 \%$ wt at Day 0 . Inset shows Guinier plot for sample prepared at $1 \% \mathrm{wt}$. Arrows indicate the peak location for the $35 \% \mathrm{w} / \mathrm{w}$ (solid arrow), $40 \% \mathrm{w} / \mathrm{w}$ (dashed arrow) and $50 \% \mathrm{w} / \mathrm{w}$ (dotted arrow). 
Table 3: Size of whey protein assemblies from SANS data (Data from Figure 6).

\begin{tabular}{ccc}
\hline $\begin{array}{c}\text { WPC solution } \\
\text { Concentration }\end{array}$ & Peak position $\mathbf{Q}\left(\AA^{-1}\right)$ & $\mathbf{d}$ - spacing $(\AA)$ \\
\hline $30 \% \mathrm{w} / \mathrm{w}$ & N/A & N/A \\
$35 \% \mathrm{w} / \mathrm{w}$ & 0.031 & 203 \\
$40 \% \mathrm{w} / \mathrm{w}$ & 0.037 & 170 \\
$50 \% \mathrm{w} / \mathrm{w}$ & 0.049 & 128
\end{tabular}

Using the Guinier method an $R_{g}$ value of ( $25 \AA \pm 9$ ) $\AA$ was calculated (Figure 5 Inset), similar to the size observed in previous measurements for the monomeric unit of $\beta$-lactoglobulin; ${ }^{52,53}$ the slight increase in the scattering intensity at the lowest scattering vectors maybe indicative of an attractive potential between proteins. It is known that $\beta$-lactoglobulin forms aggregates under certain conditions relating to the concentration, ionic strength and temperature ${ }^{54}$. The pHs for these solutions were not controlled (as this would involve adding a buffer and therefore increasing the ionic strength of the solution); typically a $\mathrm{pH}$ of 6.8 was measured for whey in $\mathrm{H}_{2} \mathrm{O}$ under the conditions used here.

In view of the time dependence of the spinning process, SANS experiments were then performed on whey protein solutions $(45 \%)$ aged in $\mathrm{D}_{2} \mathrm{O}$ over a period of 10 days. As inspection of the data in Figure 6 shows there were substantial changes to the curves with time. Further analysis (Table 4) suggested that this reflected changes in the aggregation of the protein structures. $45 \% \mathrm{w} / \mathrm{w}$ is close to the limit where precipitation started to occur, hence the broad trend for $Q_{\text {peak }}$ position to become larger suggests that the particulates become more separated as the protein becomes increasingly hydrated; the peaks also tend to become broader suggesting a less defined structure. This all supports the idea that (as expected) the protein is becoming increasing hydrated with time. The radius of gyration for the aggregated material increases after a day when comparing a fresh solution (0 days) to one prepared before that (1 day - 10 days), indicating that the structure formed becomes larger with time. 
The aggregate size is $\sim 6$ to 10 times larger than the measured average molecular size as was measured in the dilute solution.

a

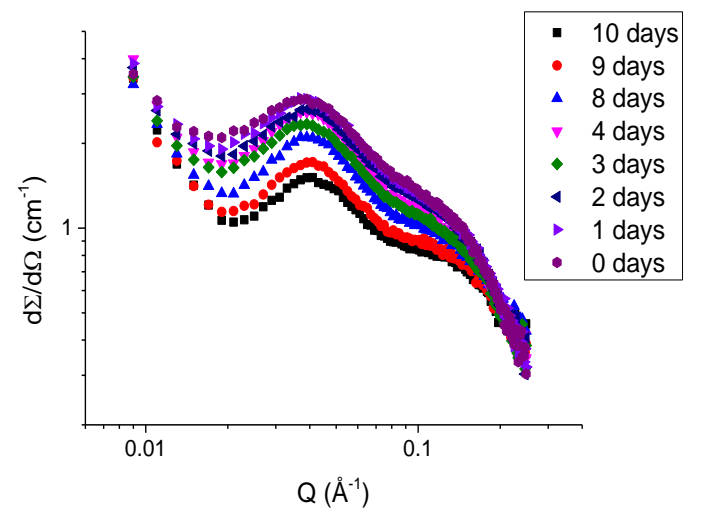

b

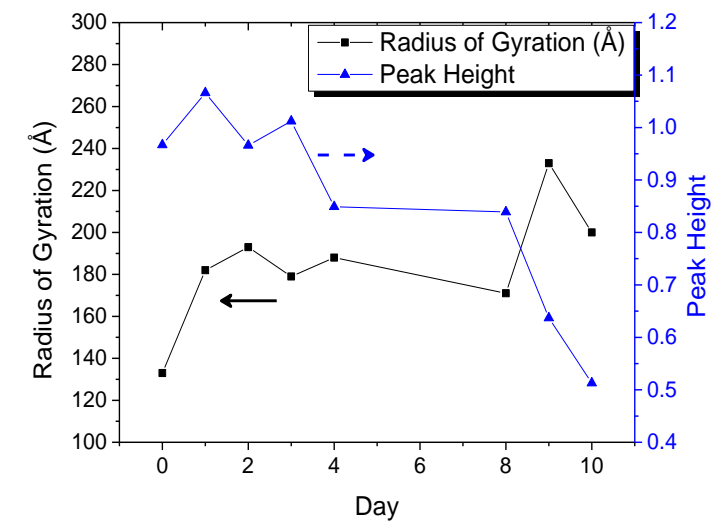

Figure 6: a) SANS of $45 \%$ w/w WPC in $\mathrm{D}_{2} \mathrm{O}$ prepared from 0 - 10 days before being subjected to neutron scattering b) Values of variation in radius of gyration of measured cluster size ( $\boldsymbol{\Xi})$ and the peak height $(\boldsymbol{\Delta})$ for solutions data in a).

Table 4: SANS of $45 \%$ w/w WPC in $\mathrm{D}_{2} \mathrm{O}$ prepared 10 days before beam time to zero days before beam time (Data obtained from analysis of Figure 6a).

\begin{tabular}{cccc}
\hline Day & Radius of Gyration $(\mathbf{\AA})$ & Peak Centre & Peak Height \\
\hline 10 & 200 & 0.041 & 0.513 \\
9 & 233 & 0.041 & 0.637 \\
8 & 171 & 0.037 & 0.839 \\
4 & 188 & 0.039 & 0.849 \\
3 & 179 & 0.039 & 1.012 \\
2 & 193 & 0.039 & 0.966 \\
1 & 182 & 0.037 & 1.066 \\
0 & 133 & 0.039 & 0.967
\end{tabular}

In view of the results on the impact of stirring described above, SANS data was obtained for solutions that were stirred and not stirred, the results of which are shown in Figure 7. There is a certain amount of apprent random variability in the data but the general trend is clear; there is some difference in the solutions and the differences increase with time. We have applied a simple analysis to the curves with the data displayed in Table 5. 
a

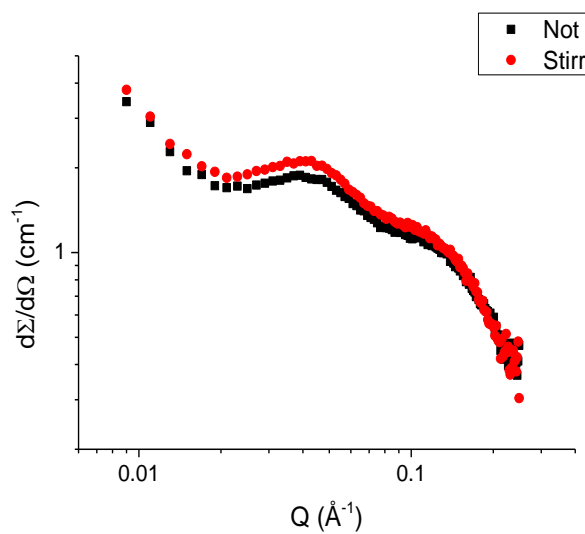

b

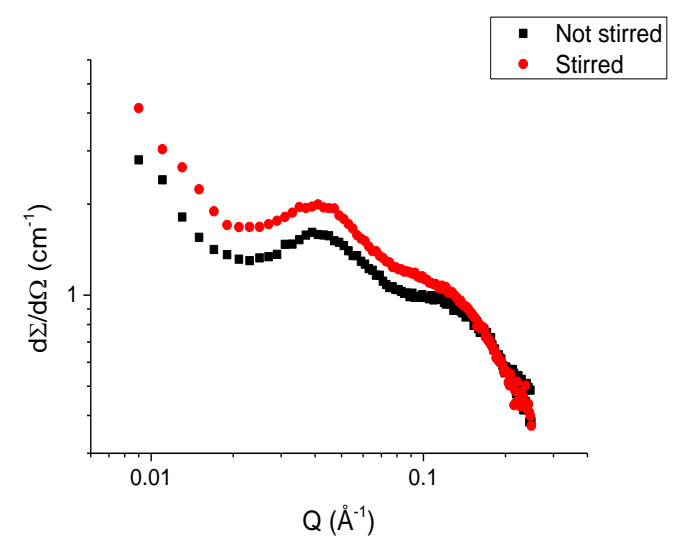

Figure 7: SANS of $45 \%$ w/w WPC in $\mathrm{D}_{2} \mathrm{O}$ Prepared with $(\bullet)$ and without stirring (•) at a) 1 day and b) 5 days before neutron scattering was performed on the solution.

Table 5. SANS of $45 \%$ w/w WPC in $\mathrm{D}_{2} \mathrm{O}$ Prepared with and without stirring 5 days to 1 day before being subjected to SANS.

\begin{tabular}{cccc}
\hline Days before SANS & Sample & Peak centre & Height \\
\hline 5 & Non-stirring & 0.041 & 0.391 \\
& Stirring & 0.043 & 0.470 \\
4 & Non-stirring & 0.041 & 0.366 \\
& Stirring & 0.041 & 0.479 \\
& & & 0.412 \\
& Non-stirring & 0.041 & 0.439 \\
& Stirring & 0.039 & 0.397 \\
& Non-stirring & 0.039 & 0.436 \\
& Stirring & 0.041 & 0.337 \\
& & & 0.465
\end{tabular}

The results from Figure 7 would indicate that although the peak position or height does not substantially change over time of the 5 day period (similar to the results displayed in Table 4). The peak heights are different between the stirred and non-stirred samples and we attribute this to the hydration levels of the aggregated structures. With the constant agitation of the stirring procedure, the molecules would be experiencing a higher degree of motion; therefore the aggregated structures would not be hydrated to the same extent as a solution left to stand.

We can develop an understanding of how this relates to the earlier observed viscosity measurements. The aggregated structures formed, and the molecular weight of the whey 
protein in solution are the key factors that determine how the dynamic viscosity is influenced by time and concentration ${ }^{55,56}$. When the concentration of whey protein solution was equal to or over $30 \% \mathrm{w} / \mathrm{w}$, aggregation of globular particles can occur between the protein molecules. Higher concentrations lead to more interactions and larger aggregates forming, resulting in the high dynamic viscosity. Physical interactions between molecules are easy to break at low stress, therefore stirring could not only increase the molecular movement by accelerating the substance dissolved and prompting the molecule aggregation in the initial stage, but also prevent the weaker intermolecular forces increasing the dynamic viscosity by breaking some of physical interactions between molecules. This would account for the data from the 40 and $45 \% \mathrm{w} / \mathrm{w}$ samples. It should be noted that these interactions may be a requirement for the electrospinning process to occur in this case ${ }^{57}$.

\subsection{WPC Electrospun Fibres}

In light of the observed structural changes in the material with time, electrospinnability of these solutions was tested on the same basis. Figure 8 shows SEM micrographs from attempts to spin the concentrated WPC solutions $(45 \% \mathrm{w} / \mathrm{w})$ subjected to stirring from day 0 to day 5 . It was found that both stirred and non-stirred whey protein polymer solutions with concentrations lower than $40 \%$ could not produce fibres; presumably due to their low viscosity (Figure 4). At these low concentrations, beads were produced instead of fibres during the electrospinning process in line with reports elsewhere ${ }^{58,59}$. The concentration of a polymer solution is strongly correlated with the viscosity of the solution ${ }^{60,61}$. Generally, a low concentration of polymer solution produces a low viscosity and has insufficient entanglements for electrospinning to occur. For polymer solutions of low viscosity, surface 
tension was is also a consideration and a high value tends to favours bead generation ${ }^{62}$. However sufficient entanglements could modify the effect of solution surface tension, and maintain an acceptable viscosity at a low polymer solution concentration ${ }^{63}$. Therefore, sufficient molecular entanglement is the other solution parameter that played a significant role in fibre generation. The viscosity of polymer solution and hence the number of chain engagements increased with either an increase in the polymer solution concentration or with the length of the polymer chain. Consequently, a polymer solution with both optimal concentrations, sufficient chain entanglements and hence an acceptable viscosity should be readily spun into a polymeric fibre. It was not possible to electrospin Whey protein solutions at $45 \%$ wt left standing. This is related to the high viscosity of the standing solutions as previously shown above (Figure 4). However, the solutions that were subjected to stirring began to show signs of fibre formation after several days without the requirement for the PEO as an additive. Due to the stirring partially breaking up interactions between neighbouring agglomerated materials, the viscosity was at an optimum level to allow for the spinning process to occur (Figure 9). Figure 9 shows the viscosity of the WPC solutions has obviously increased with the increase in time of stirring. Generally, a rise in the viscosity of the polymer solution results in an increase in the fibre diameter ${ }^{64}$, however, an increase in the viscosity of the WPC solution was found to produce a reduction in the fibre size and a more uniform fibre. Meanwhile, the number and size of chain entanglements could affect the size of the fibre as well ${ }^{63}$. 

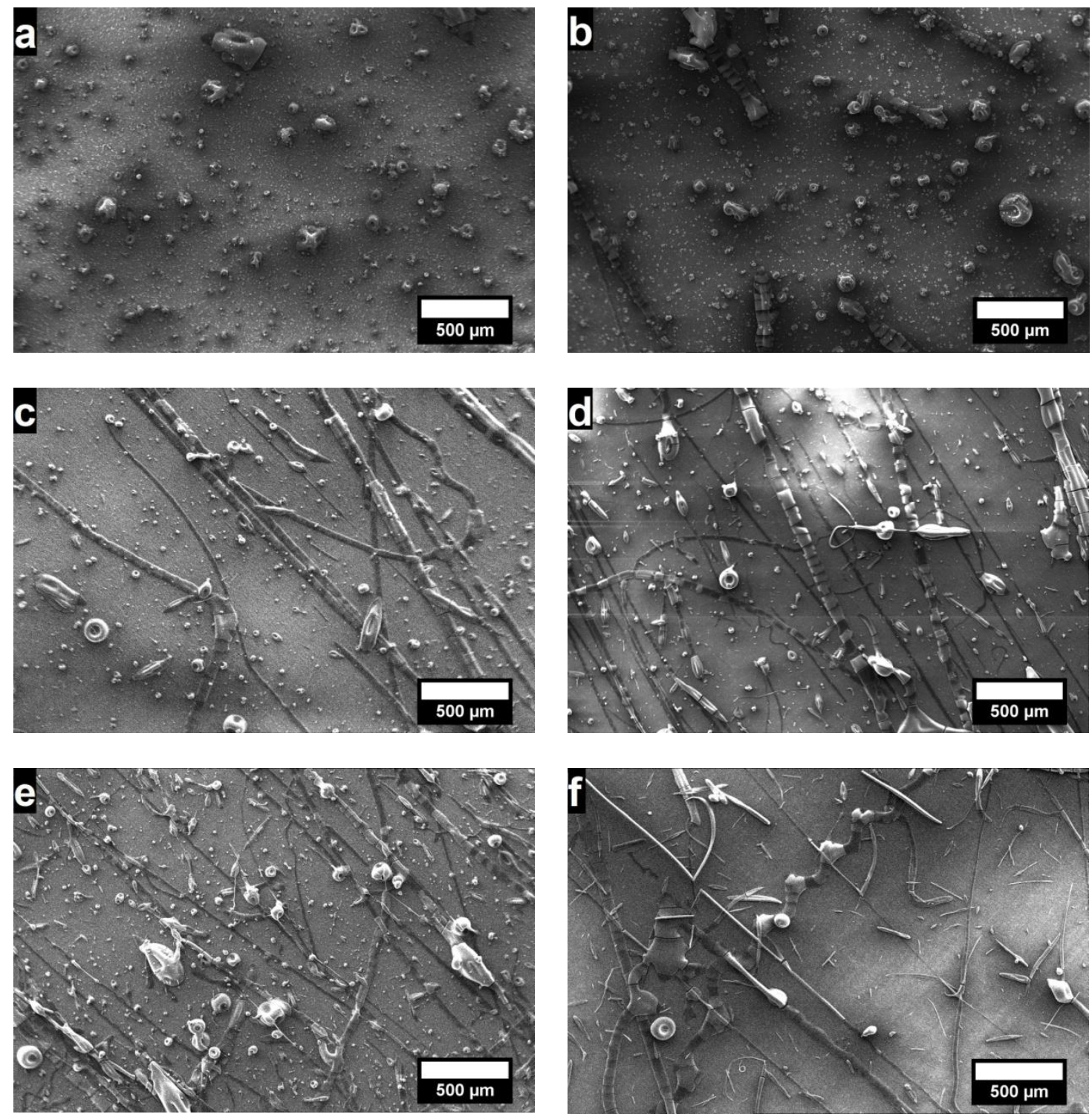

Figure 8: SEM micrographs of electrospun material produced from $45 \% \mathrm{w} / \mathrm{w}$ WPC polymer solution with stirring over time from 45\% w/w stirred WPC solution at a) Day 0 b) Day 1 c) Day 2 d) Day 3 e) Day 4 and f) Day 5 


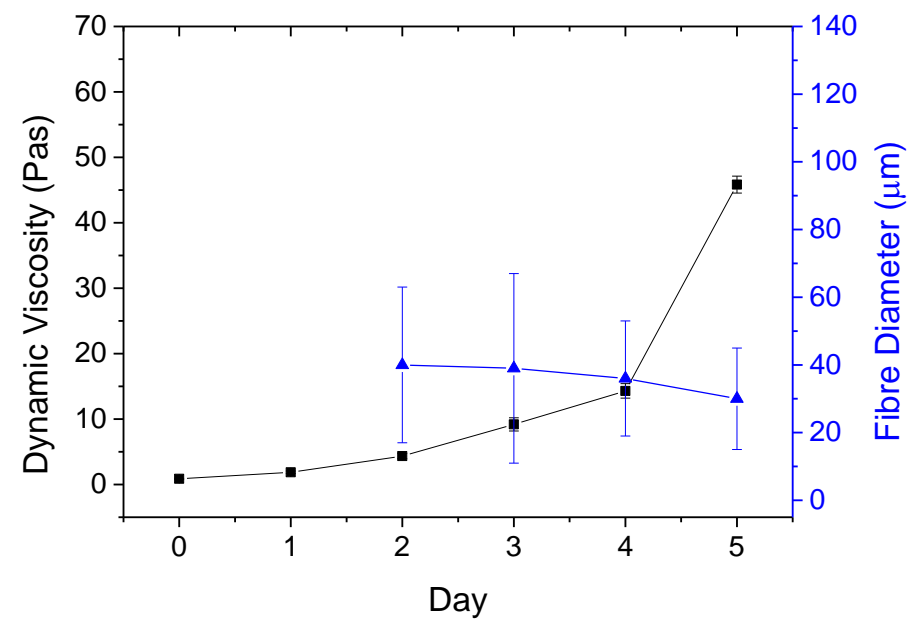

Figure 9: Changes of dynamic viscosity (घ) of $45 \%$ w/w WPC polymer solution with time and changes of the size of electrospun fibre $(\boldsymbol{\Delta})$ produced from aged polymer solution from 2 days to 5 days. (Fibre size $=90 \pm$ sd, dynamic viscosity of polymer solution $=9 \pm$ sd)

From the SANS data we have observed that the size of the aggregated material was between 6 - 10 times the size of the whey protein molecules, perhaps on a sufficient scale that their interactions act effectively like a polymer that can entangle or at least interact to the extent that they can hold the fibrous structure together. After several days the material has sufficient interactions that the viscosity has increased to an optimal value for electrospinning, allowing for the production of fibrous material. The agitation from stirring possibly aids in the initial dissolution of the material, as well as breaking up large scale network structures that maybe developing throughout the solution, which may explain the much higher viscosities observed for the solutions allowed to stand. After several days there are sufficient interactions to better hold the material together, hence the higher viscosity and more fibrous looking appearance of the spun material observed after 5 days,

The morphology of these electrospun fibres differed considerably from these created using PEO as an additive to the polymer mix. Their diameters were considerably increased and they showed evidence of both surface and longitudinal fracturing. Although the material exhibits sufficient interactions to now form fibrous structures, they are not sufficiently strong enough to hold the material intact and hence a breakage of the material is observed. This 
morphology would suggest that the increased material load on the electrospinning process has prevented a fully drawn out fibre from being formed, suggesting that the major role of the PEO is to allow the WP to spin with a lower degree of interaction between the WP molecules. The PEO could be acting by a number of mechanisms (e.g. "bridging" protein aggregates, interfering with protein tertiary structure) but the most likely given the structure of PEO is some sort of interaction with the hydrogen bonding present ${ }^{45,46,48}$.

\section{Conclusions}

This study has shown the successful production of electrospun fibres from a carrier/whey protein system under certain conditions. The incorporation of relatively low levels of polyethylene oxide into the system allowed the production of composite fibre materials with diameters in the region of $100-400 \mathrm{~nm}$. This suggests that the nature of the carrier/protein mixture may depend on the establishment of a two phase system which may "flip" if the ratio of protein to PEO changes significantly. The morphology of the electrospun fibre tended to be "twisted" in this study. A time dependence of blended solution viscosity and fibre morphology were found. A particularly interesting feature of these studies is that apparently very low levels of PEO (1\% w/w in solution leading to $\sim 3 \% \mathrm{wt}$ in the final fibre) are required to produce sub-micron fibres. This suggests that the role of the PEO is to interact with the protein structures to form spinnable chains; at these concentrations PEO on its own would not spin. As PEO is non-toxic and already used in pharmaceuticals, it offers a route to preparation of sub-micron fibres that have potential use in the food industry. 
Whey protein fibres could be produced from aqueous solution but only under carefully controlled conditions. It is fair to say the fibres were much larger in diameter than those fibre produced from WPC/PEO blended polymer solution. In addition, the morphology of thicker fibres suggested some fracturing during the spinning process (cracks appeared approximately $0.1 \mathrm{~mm}$ apart). The properties of the solutions from which the whey protein were electrospun have been studied and the evidence is clear that there are substantial changes with time. These changes can be influenced by stirring. In particular it seems that time-dependent protein reorganisation favours electrospinning although there is a competing effect from aggregate formation.

\section{Acknowledgements:}

SDM's contribution was funded by the European Union Seventh Framework Programme (FP7/2007-2013) under grant agreement n²63017, Project "NanoCelluComp".

GRM work is supported by the Fundação para a Ciência e a Tecnologia (Portugal) through the Project reference UID/Multi/04044/2013. The neutron scattering data were obtained at the STFC ISIS facility at Chilton UK (application number RB1310345) and we thank Steve King for help with the experiments. The microscopy was performed in the Electron microscopy Lab (EMLab) at the University of Reading, UK. The Photron Fastcam MC-1 high speed camera was provided by the EPSRC Engineering Instrument Pool. 


\section{References:}

${ }^{1}$ Bryant, C. M.; and McClements D. J. Molecular basis of protein functionality with special consideration of cold-set gels derived from heat- denatured whey. Trends Food Sci. Technol. 1998, 9, 143-151

2 Panyam, D.; Kilara, A. Enhancing the functionality of food proteins by enzymatic modification. Trends Food Sci. Technol., 1996, 7, 120 - 125

${ }^{3}$ Onwulata, C. I.; Tomasula, P. Whey Texturization: A Way Forward. Food Technol. (Chicago, IL, U. S.) 2004, $58,50-54$.

${ }^{4}$ MaHam, A.; Tang, Z.; Wu, H.; Wang, J.; Lin, Y. Protein-Based Nanomedicine Platforms for Drug Delivery. Small 2009, 5, 1706-1721.

${ }^{5}$ Satpathy, G.; Rosenberg, M. Encapsulation of chlorothiazide in whey proteins: effects of wall-to-core ratio and cross-linking conditions on microcapsule properties and drug release. J. Microencapsulation 2003, 20, 227245.

${ }^{6}$ Livney, Y.; Verespej, E.; Dalgleish, D. G. Steric effects governing disulfide bond interchange during thermal aggregation in solutions of $\beta$-lactoglobulin B and $\alpha$-lactalbumin. J. Agric. Food Chem. 2003, 51, 8098-8106.

7 Haque, M. A.; Timilsena, Y. P.; Adhikari B. Food Proteins, Structure, and Function. Reference Module in Food Science 2016 DOI: 10.1016/B978-0-08-100596-5.03057-2

${ }^{8}$ Kadim, I. T.; Mahgoub, O.; Baqir, S.; Faye, B.; Purchas, R. Cultured meat from muscle stem cells: A review of challenges and prospects. J. Integr. Agric. 2015, 14, 222-233

${ }^{9}$ Verbeke, W.; Sans, P.; Loo, E. J. V. Challenges and prospects for consumer acceptance of cultured meat. $J$. Integr. Agric. 2015, 14, 285-294

${ }^{10}$ Sankar, S., Sharma, C. S., Rath, S. N., and Ramakrishna, S. (2016) Electrospun nanofibres to mimic natural hierarchical structure of tissues: application in musculoskeletal regeneration. J Tissue Eng Regen Med, doi: $10.1002 /$ term.2335.

11 Reneker, D. H.; Chun, L. Nanometre diameter fibres of polymer, produced by electrospinning. Nanotechnology 1996, 7, 216-223.

${ }^{12}$ Severt, S.Y., Maxwell, S. L., Bontrager, J. S., Leger, J. M., and Murphy, A. R., Mimicking muscle fiber structure and function through electromechanical actuation of electrospun silk fiber bundles, J. Mater. Chem. B, 2017, 5, 8105-8214.

${ }^{13}$ Frenot, A.; Chronakis, I. S. Polymer nanofibers assembled by electrospinning. Curr. Opin. Colloid Interface Sci. 2003, 8, 64-75.

${ }^{14}$ Theron, S. A.; Yarin, A. L.; Zussman, E.; Kroll, E. Multiple jets in electrospinning: Experiment and modeling. Polymer 2005, 46, 2889-2899.

${ }^{15}$ Reneker, D. H.; Yarin, A. L.; Fong, H. Koombhongse, S.; Bending instability of electrically charged liquid jets of polymer solutions in electrospinning. J. Appl. Phys. 2000, 87, 4531-4547.

${ }^{16}$ Huang, Z. M.; Zhang, Y. Z.; Kotaki, M.; Ramakrishna, S. A review on polymer nanofibers by electrospinning and their applications in nanocomposites. Compos. Sci. Technol. 2003, 63, 2223-2253.

${ }^{17}$ Luu, Y. K.; Kim, K.; Hsiao, B. S.; Chu, B.; Hadjiargyrou, M. Development of a nanostructured DNA delivery scaffold via electrospinning of PLGA and PLA-PEG block copolymers. J. Controlled Release. 2003, 89, 341353.

${ }^{18}$ Subbiah, T.; Bhat, G. S.; Tock, R. W.; Parameswaran, S.; Ramkumar, S. S. Electrospinning of nanofibers. J. Appl. Polym. Sci. 2005, 96, 557-569.

19 Welle, A.; Kroger, M.; Doring, M.; Niederer, K.; Pindel, E.; Chronakis, S. Electrospun aliphatic polycarbonates as tailored tissue scaffold materials. Biomaterials 2007, 28, 2211-2219.

${ }^{20}$ Vardhanabhuti, B.; Foegeding, E. A. Rheological Properties and Characterization of Polymerized Whey Protein Isolates. J. Agric. Food Chem. 1999, 47, 3649-3655.

${ }^{21}$ Roefs, S. P. F. M.; De Kruif, K. G. A Model for the Denaturation and Aggregation of $\beta$-Lactoglobulin. Eur. J. Biochem. 1994, 226, 883-889.

22 Jiang, H.; Hu, Y.; Li, Y.; Zhao, P.; Zhu, K.; Chen, W. A facile technique to prepare biodegradable coaxial electrospun nanofibers for controlled release of bioactive agents. J. Controlled Release 2005, 108, 237-243.

${ }^{23}$ Wongsasulak, S.; Kit, K. M.; McClements, D. J.; Yoovidhya, T.; Weiss, J. The effect of solution properties on the morphology of ultrafine electrospun egg albumen-PEO composite fibers. Polymer 2007, 48, 448-457.

${ }^{24}$ Min, B.; Lee, G.; Kim, S. H.; Nam, Y. S.; Lee, T. S.; Park, W. H. Electrospinning of silk fibroin nanofibers and its effect on the adhesion and spreading of normal human keratinocytes and fibroblasts in vitro. Biomaterials 2004, 25, 1289-1297. 
${ }^{25}$ Sullivan, S. T.; Tang, C.; Kennedy, A.; Talwar, S.; Khan, S. A. Electrospinning and heat treatment of whey protein nanofibers. Food hydrocolloids 2014, 35, 36-50.

${ }^{26}$ Jin, H. J.; Chen, J.; Karageorgiou, V.; Altman, G. H; Kaplan, D. L. Human bone marrow stromal cell responses on electrospun silk fibroin mats. Biomaterials 2004, 25, 1039-1047.

${ }^{27}$ Ramji, K.; Shah, R. N. Electrospun soy protein nanofiber scaffolds for tissue regeneration. J. Biomater. Appl. 2014, 29, 411-422.

${ }^{28}$ Kang, J.; Kotaki, M.; Okubayashi, S.; Sukigara, S. Fabrication of electrospun eggshell membrane nanofibers by treatment with catechin. J. Appl. Polym. Sci. 2009, 117, 2042-2049.

${ }^{29}$ Vega-Lugo, A. C.; Lim, L. T. Effects of poly(ethylene oxide) and $\mathrm{pH}$ on the electrospinning of whey protein isolate, J. Polym. Sci., Part B: Polym. Phys. 2012, 50, 1188-1197.

${ }^{30}$ Nie, H.; He, A.; Wu, W.; Zheng, J.; Xu, S.; Li, J.; Han, C. C. Effect of poly(ethylene oxide) with different molecular weights on the electrospinnability of sodium alginate. Polymer 2009, 50, 4926-4934.

${ }^{31}$ Vega-Lugo, A. C.; Lim, L. T. Electrospinning of Soy Protein Isolate Nanofibers. $\quad$ J. Biobased Mater. Bioenergy 2008, 2, 223-230.

${ }^{32}$ Alborzi, S.; Lim, L. T.; Kakuda, Y. Electrospinning of sodium alginate-pectin ultrafine fibers. J. Food Sci. 2010, 75, 100-107.

${ }^{33}$ Huang, Z. M.; Zhang, Y. Z.; Ramakrishna, S.; Lim, C. T. Electrospinning and mechanical characterization of gelatin nanofibers. Polymer 2004, 45, 5361-5368.

${ }^{34}$ Heenan, R. K.; Penfold. J.; King, S. M. SANS at Pulsed Neutron Sources: Present and Future Prospects. $J$. Appl. Crystallogr. 1997, 30, 1140-1147.

${ }^{35}$ Wignall, G. D.; Bates, F. S. Absolute calibration of small-angle neutron scattering data. J. Appl. Crystallogr. 1987, 20, 28-40.

${ }^{36}$ Lee, K. Y.; Jeong, J.; Kang, Y. O.; Lee S. J.; Park. W. H. Electrospinning of polysaccharides for regenerative medicine. Adv. Drug Delivery Rev. 2009, 61, 1020-1032

${ }^{37}$ Sen, S.; Davis, F. J.; Mitchell, G. R.; Robinson, E. Conducting nanofibres produced by electrospinning. $J$. Phys.: Conf. Ser. 2009, 183, 012020 DOI: 10.1088/1742-6596/183/1/012020

${ }^{38}$ Haghi, A. K.; Akbari, M.; Trends in electrospinning of natural nanofibers. Physica Status Solidi(a) 2007, 204, 1830-1834

39 Sukigara, S.; Gandhi, M.; Ayutsede, J.; Micklus, M.; Ko, F. Regeneration of Bombyx mori silk by electrospinning — part 1: processing parameters and geometric properties. Polymer 2003, 44, 5721-5727.

${ }^{40}$ Zuo, W.; Zhu, M.; Yang, W.; Yu, H.; Chen, Y. Zhang, Y.; Experimental study on relationship between jet instability and formation of beaded fibers during electrospinning. Polym. Eng. Sci. 2005, 45, 704-709.

${ }^{41}$ Koombhongse S, Liu W, Reneker DH; Flat polymer ribbons and other shapes by electrospinning. Journal of Polymer Science, Part B: Polymer Physics, 2001;39, 2598-2606.

${ }^{42}$ Kubel, C.; Gonzalez-Ronda, L.; Drummy, L. F. Martin, D. C.; Defect-mediated curvature and twisting in polymer crystals. J. Phys. Org. Chem. 2000, 13, 816-829.

${ }^{43}$ Godinho, M. H., Canejo, J. P., Pinto, L. F. V., Borges J. P., and Teixeira, P. I. C., How to mimic the shapes of plant tendrils on the nano and microscale: spirals and helices of electrospun liquid crystalline cellulose derivatives, Soft Matter, 2009, 5, 2772-2776.

${ }^{44}$ Godinho, M. H.,. Canejo, J. P, Feio G., and Terentjev E. M.,, Self-winding of helices in plant tendrils and cellulose liquid crystal fibers Soft Matter, 2010, 6, 5965-5970.

45 Jeon, S. I.; Lee, J. H.; Andrade, J. D.; De Gennes, P. G. Protein-surface interactions in the presence of polyethylene oxide: I. Simplified theory. J. Colloid Interface Sci. 1990, 142, 149-158.

${ }^{46}$ Jeon, S. I.; Andrade, J. D., Protein — surface interactions in the presence of polyethylene oxide: II. Effect of protein size. J. Colloid Interface Sci. 1990, 142, 149-158.

${ }^{47}$ Israelachvili, J. The different faces of poly(ethylene glycol). Proceedings of the National Academy of Sciences 1997, 94, 8378-8379

${ }^{48}$ Sheth, S. R.; Leckband, D. Measurements of attractive forces between proteins and end-grafted poly(ethylene glycol) chains. Proc. Natl. Acad. Sci. U. S. A. 1997, 94, 8399-8404.

${ }^{49}$ Genovese, D. B.; Lozano, J. E.; Rao, M. A. The Rheology of Colloidal and Noncolloidal Food Dispersions. J. Food Sci.2007, 72, 11-20.

${ }^{50}$ Hermansson, A. M. Functional Properties of Proteins For Foods-Flow Properties.

J. Texture Stud. 1975, 5, 425-439.

${ }^{51}$ Boland, M. In Handbook of food protein, 1st ed.; Phillips, G. O.; Williams, P. A. Eds. Woodhead publishing limitied: Cambridge, 2011; Vol. 3, p31

52 Vogtt, K.; Javid, N.; Alvarez, E.; Sefcik, J.; Bellissent-Funel, M. C. Tracing nucleation pathways in protein aggregation by using small angle scattering methods, Soft Matter, 2011, 7, 3906-3914. 
53 Verheul, M.; Pedersen, J. S.; Roefs, S. P. F. M.; De Kruif, K. G. Association Behavior of Native $\beta$ Lactoglobulin, Biopolymers, 1999, 49, 11-20.

54 Hong, Y. H.; McClements, D. J. Formation of Hydrogel Particles by Thermal Treatment of $\beta$ Lactoglobulin-Chitosan Complexes. J. Agric. Food Chem. 2007, 55, 5653-5660.

${ }^{55}$ Dissanayake, M.; Ramchandran, L.; Vasiljevic, T. Influence of $\mathrm{pH}$ and protein concentration on rheological properties of whey protein dispersions. Int. Food Res. J. 2013, 20, 2167-2171.

56 Nakasako, M.; Finney, J. L.; Rand. P.; Engberts, J. B. F. N.; McKendry, R.; Zaccai, G. Water-protein interactions from high-resolution protein crystallography. Philos. Trans. R. Soc., B 2004, 359, 1191-1206.

${ }^{57}$ Elliott, D. E.; Davis F. J.; Mitchell, G. R.; Olley, R. H. Structure development in electrospun fibres of gelatin. J. Phys.: Conf. Ser. 2009, 183

${ }^{58}$ Fong, H.; Chun, I.; Reneker, D. H. Beaded nanofibers formed during electrospinning. Polymer 1999, 40, 4585-4592.

${ }^{59}$ Mckee, M. G.; Wilkes, G. L.; Colby, R. H.; Long, T. E. Correlations of Solution Rheology with Electrospun Fiber Formation of Linear and Branched Polyesters. Macromolecules 2004, 37, 1760-1767.

${ }^{60}$ Ki, C. S.; Baek, D. H.; Gang, K. D.; Lee, K. H.; Um, I. C.; Park, Y. H. Characterization of gelatin nanofiber prepared from gelatin-formic acid solution. Polymer 2005, 46, 5094-5102.

${ }^{61}$ Jun, Z.; Hou, H. Q.; Schaper, A.; Wendorff, J. H.; Greiner, A. Poly-L-lactide nanofibers by electrospinning Influence of solution viscosity and electrical conductivity on fiber diameter and fiber morphology. e-Polymers 2003, 9, 1-9.

${ }^{62}$ Doshi, J.; Reneker, D. H. Electrospinning process and applications of electrospun fibers. J. Electrost. 1995, 35, 151-160.

63 Tan, S. H.; Inai, R.; Kotaki, M.; Ramakrishna, S. Systematic parameter study for ultra-fine fiber fabrication via electrospinning process. Polymer 2005, 46, 6128- 6134.

${ }^{64}$ Deitzel, J. M.; Kleinmeyer, J.; Harris, D.; Tan, N. C. B. The effect of processing variables on the morphology of electrospun nanofibers and textiles. Polymer 2001, 42, 261-272. 